\title{
Spatial Price Transmission and Trade in the European Dairy Sector
}

\author{
Zoltán Bakucs ${ }^{1,2}, Z_{\text {sófia Benedek }}^{1}$, Imre Fertö ${ }^{1,3}$ \\ ${ }^{1}$ Institute of Economics, Centre for Economic and Regional Studies of the Hungarian Academy of Sciences, \\ Budapest, Hungary \\ ${ }^{2}$ Corvinus University of Budapest, Hungary \\ ${ }^{3}$ Kaposvár University, Hungary
}

\begin{abstract}
There exists a large literature on spatial price transmission in agro-food sectors, but research on milk sector is relatively limited. In addition, we cannot generalize the results of these studies due to their diversity in terms of methodology, periods and countries. The aim of the paper is precisely to generalize, or at least broaden the evidence on horizontal price transmission in European Union dairy market. We employ two stages approach. First, we test whether Law of One Price exists among European Union member states. Second, we try to explain our findings based on gravity model framework in a binary choice setting. Our results are in line with theoretical expectations: the volume of milk traded and Eurozone membership positively, the geographical distance negatively affects the probability of perfect price transmission. In addition, we show that horizontal price transmission is dependent on political group variables (New Member States versus Old Member States).
\end{abstract}

\section{Keywords}

Spatial price transmission, EU milk market, trade.

JEL code: F14, F15, Q11, Q17

Bakucs, Z., Benedek, Z. and Fertö, I. (2019) "Spatial Price Transmission and Trade in the European Dairy Sector", AGRIS on-line Papers in Economics and Informatics, Vol. 11, No. 2, pp. 13-20. ISSN 1804-1930. DOI 10.7160/aol.2019.110202.

\section{Introduction}

Research on the spatial price transmission and integration is often used to test the efficiency of agricultural markets. On a spatially integrated market, price information should freely and fully be transmitted between trading partners. Not surprisingly, one of the most important targets of the European Union's (EU) Common Agricultural Policy (CAP) is to facilitate the spatial integration of agricultural markets within the individual member states as well as at the whole EU level by enhancing price discovery mechanisms.

Horizontal and vertical price transmission papers are abundant: an August 2016 AgEcon Search (http://ageconsearch.umn.edu) on 'price transmission' term results 546, on 'Law of One Price' 115, on 'market integration' 1837, and finally, on 'price integration' 1087 papers. Whilst some of the search results above are surely redundant, the numbers emphasise the popularity of these topics. The analysis of price transmission is and has been an econometrician's playground. Without completeness, some of the ground-breaking methodologies such as threshold cointegration, smooth transition and some Markov switching models were developed and tested using this framework, (see e.g. Enders, 2010). Most of these studies focus on single country-multi region cases (e.g. Brosig et al., 2011), country pairs (e.g. Bakucs et al., 2015) or multi-country framework (e.g. Emmanouilides and Fousekis, 2015). Recently, the 2007-2008 and 2010-2011 price spikes generated a renewed interest in spatial price integration (e.g. Goetz and von Cramon-Taubadel, 2008; Esposti and Listorti, 2013).

Assessing whether markets are integrated, whether the Law of One Price holds, or whether price transmission is symmetric or indeed asymmetric are themselves interesting research questions, since price transmission theory provides detailed theoretical explanations (see e.g. the discussion in Bakucs et al. 2014). In the light of this 
abundance, the lack of empirical research uncovering the determinants of price transmission is perhaps even more striking. 16 years ago, in a seminal paper Peltzman (2000) called for the reconciliation of price transmission theory and empirical analysis, yet not much has been done since.

The weak connection between price transmission theory and empirical papers is mainly because the classical price transmission methodology employs time series econometrics thus it was developed using only price data, not allowing the inclusion of further covariates as determinants of price transmission. More recent techniques may directly or indirectly account for non-price variable effects as well, but encounter data availability problems. As Stephens et al. (2012) rightly argue, 'lack of available complementary price, trade flow and transaction cost data has hampered the analysts' ability to test empirically whether or not trade flows are the main mechanisms behind spatial equilibrium patterns' (p. 454). There are however several possible solutions to the problem of joint analysis of horizontal price transmission/ market integration and its determinants.

A possibility to indirectly incorporate trade (or trade costs) into price transmission analysis is the application of non-linear threshold price transmission models which allow adjustment asymmetries (e.g. Enders and Siklos, 2001) or indirectly account for unobserved transaction costs and define regimes with varying adjustment and short-run parameters (e.g. Hansen and Seo, 2002). Perhaps the most intuitive of this model class is the Gonzalo and Pitarakis (2006) procedure, which is capable of directly defining price transmission regimes (including regime dependent long-run relationships) dependent on an exogenous stationary variable (e.g. trade, market share, etc.). Empirical examples of the latter include Goetz and Cramon-Taubadel (2008) for German apple market or more recently, Bakucs et al. (2015) estimating trade volume dependent Slovenian and Hungarian wheat market integration models.

Second, given the wealth of price transmission papers, the use of meta-regression techniques in order to test second stage explanatory variables is a method at hand. This has been done for both vertical (e.g. Greb et al., 2012; Bakucs et al., 2014) and horizontal (e.g. Kouyaté and Cramon - Taubadel, 2016) price transmission. Besides the often not directly comparable methodologies, the publication bias might be a serious issue when first stage data originates from published research. As an example, Greb et al. (2012) find that cointegration occurs in $79 \%$ of all analysed commodity markets originating from published research, yet this ratio halves to $43 \%$ when the integration of similar commodity markets was directly assessed using FAO's GIEWS dataset.

In this paper we propose a new, systemic approach - which overcomes the comparability and publication bias issues discussed above - to analyze the changes in the dairy market during the previous decade from a market integration and efficiency perspective. (Following Barrett (2001), Holst and von Cramon-Taubadel (2013) discuss the distinction between market efficiency as result of price equilibrium in geographically distinct regions, and market integration as result of physical trade flows. In practice however, most importantly because of the lack of comparable frequency trade data, these terms are often used interchangeably.) First, we estimate all possible long-run cointegrating models between milk price pairs. We then apply discrete-choice models to assess the role of trade and other variables originating from gravity models affecting market integration. To the best of our knowledge, this approach has not been applied in empirical research. It is important to observe that none of the papers reviewed in this section focus on milk price integration. It is not obvious why this CAP regulated sector was neglected by empirical researchers.

\section{Materials and methods}

\section{Spatial integration of EU raw milk markets}

\section{Law of One Price}

Markets that pass price information quickly and fully, are considered to be perfectly integrated and commonly assumed to be efficient. Tomek and Robinson (2003) define the two axioms of the international price differences theory (For a detailed discussion on the methodological issues and generally the empirics of horizontal market integration see the excellent review paper of Listorti and Esposti (2012)):

- $\quad$ The price difference in any two international markets involved in trade with each other equals the transfer (or transaction) costs.

- The price difference between any two international markets not involved in trade with each other is smaller than the transfer costs.

Consider two spatially different markets and denote the time varying prices of the same commodity 
as $\mathrm{P} 1 \mathrm{t}$ and $\mathrm{P} 2 \mathrm{t}$ respectively. The two markets are considered integrated, if prices corrected with transportation and other handling costs $\mathrm{K}$, are equalized:

$P_{1 t}=P_{2 t}+K$

Trade between the two markets occurs only if $\left|P_{1 t}-P_{2 t}\right|>K_{t}$. (There are however some examples of existing trade despite negative arbitrage, explained e.g. by the need of keeping trade channels open or maintaining market share.) To put it other way, the arbitrage ensures that prices of the same good traded in spatially separate international markets equalize. In the literature, this is called the Law of One Price, LOP. Empirical literature usually tests the validity of the LOP with prices expressed in logarithms, allowing the interpretation of coefficients as elasticities of transmission:

$\ln P_{1 t}=\ln \beta_{0}+\beta_{1} \ln P_{2 t}+\varepsilon_{t}$

According to the strong version of LOP, prices move perfectly together in time. Using the coefficients of equation (2), the necessary conditions are $\beta_{0}=0$, and $\beta_{1}=1$. In practice, however, the strong version of LOP only occurs very rarely, therefore a weak version of LOP was also defined. (Throughout the empirical analysis we use the weak version of LOP. Constant free cointegrating relationships are rather restrictive assumption resulting (amongst other issues) to over rejection of $\beta_{1}=1$ null hipothesis.) This states, that only the price ratio is constant, the actual price level is different due to transportation and other handling or transfer costs. Applying the notation of equation (2), the necessary restrictions $\beta_{0} \neq 0$ and $\beta_{1}=1$, i.e. $1 \%$ price change in market 2 results in a $1 \%$ change in market price 1.

\section{Methodology and empirical strategy}

Given the time series nature of milk price data, stationarity and integration properties within well specified Vector Autoregressive models are assessed first, applying the usual unit root tests for the logged price data and their first difference. Pairwise Engle and Granger type cointegration tests are employed next, followed by the estimation of bivariate cointegrating regressions (Engle and Granger, 1987). The (weaker) LOP hypothesis is tested for cointegrating price pairs only, within a Fully Modified OLS (FMOLS) framework developed by Phillips and Hansen (1990), which employs a semiparametric correction to assure unbiasedness and to allow the use of standard Wald and Chi-square tests. Using a 5\% significance level we code the result of Chi-square restriction $\beta_{1}=1$ (eq. 2) into a binary variable taking the value 1 if the LOP holds, and 0 otherwise. Throughout the estimations, to account for residual serial correlation, the Akaike criterion is used for lag length selection. The Maximum Likelihood estimator of parametric discrete-choice models is only consistent and asymptotically efficient if distributional assumptions are valid. A number of semiparametric discrete-choice models were developed (see De Luca, 2008 for more details on this model class) to overcome estimator inconsistency in the presence of unknown error distributions. In this paper we apply the the seminonparametric discrete-choice model of Gallant and Nychka (1987).

\section{Data}

It is hard to overestimate the importance of EU dairy sector. It is the second source of animal protein; the yearly average consumption in the European Union (EU) is equivalent to approximately $300 \mathrm{~kg}$ milk (Westhoek et al., 2011). Although dairy products of many EU member states are competitive on global markets (Bojnec and Fertö, 2014), intra-EU milk trade is also significant (EDA, 2014). Enlargement, policy reforms and trade liberalization are considered the most important drivers of the changes in the dairy sector; but the joint impact of these changes is rarely analysed, especially at the EU level (Bouamra-Mechemache et al., 2008). Raw milk - the subject of this research - is a homogenous (and thus directly comparable) product that has not gone through any transformation except cooling. Monthly cow's raw milk price series from 2000 January until 2014 February were obtained from the European Commission's milk market observatory (http://ec.europa. eu/agriculture/milk-market-observatory/). Following an initial data consistency analysis, the following 20 out of the possible 27 member states were included in the analysis (in descending milk production order): Germany, France, United Kingdom, Netherlands, Italy, Poland, Spain, Ireland, Denmark, Belgium, Austria, Sweden, Czech Republic, Finland, Portugal, Hungary, Lithuania, Romania, Slovakia and Latvia. Together these countries account for 97.9\% of EU27 2013 cow's milk production in 2013 (see Figure 1).

Figure 2 presents the individual country specific milk prices. Old Member States (OMS) series are composed of 170 observations, while New Member States (NMS) time series are ranging between 62 (Romania) and 146 observations (Czech Republic 


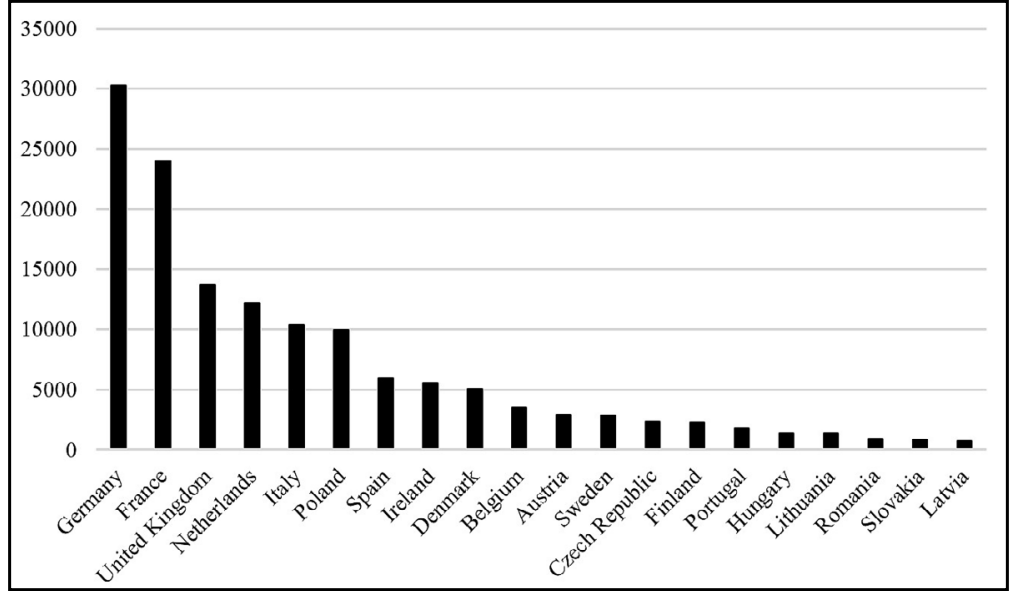

Source: Own calculations, EUROSTAT data

Figure 1: Raw milk production in 2013 (1000 tons).

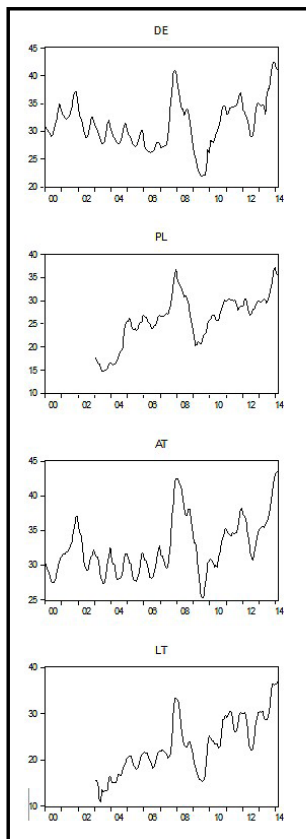

Source: own calculations

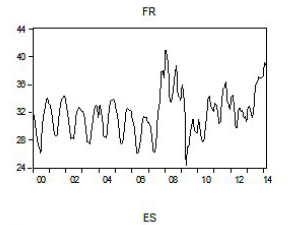

ES

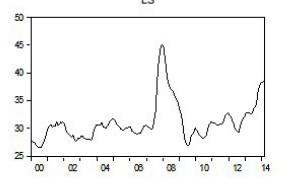

$s \in$

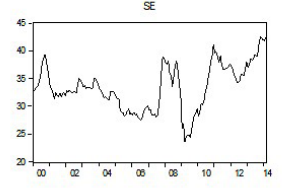

HU

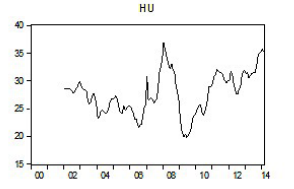

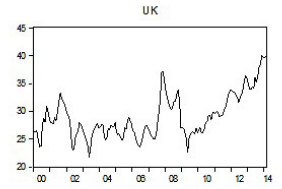

E

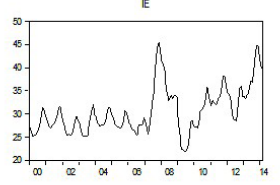

$\mathrm{cz}$
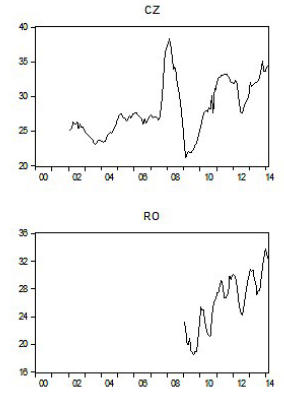

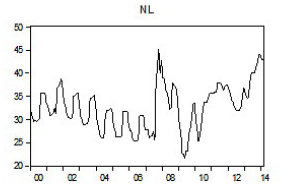

DK
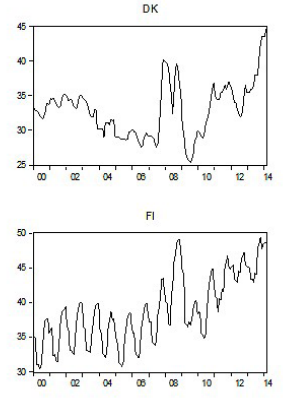

$s \kappa$

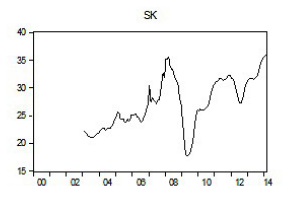

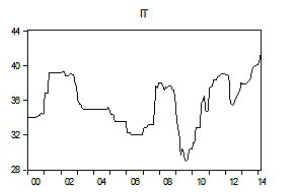

BE
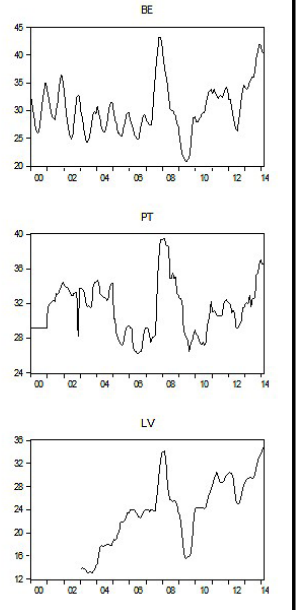

Figure 2: Raw milk prices in member states (EUR/100kg).

and Hungary). The 2007-2008 spikes followed by the 2012 price increase are clearly visible on graphs; however the inclusion of structural break dummy in test equations did not prove significant or did not alter results.

In spirit of market integration models we apply logarithm export volume as a prime candidate for second stage explanatory variables. Gravity models emphasise the role of trade cost explaining trade flows. Thus, we employ standard trade cost variables (logarithm) distance between trading partners' capitals, measured in kilometres, the existence of common border, and Euro dummy as a common currency. Moreover, we control regional/political division of European Union using different dummy variables:

- $\quad \ln \operatorname{export}(q)$ : is a log of export value (volume) from country 2 to country 1 (using the notation of eq. 2) in 1000 dollars (tons) (source: World Integrated Trade Solution, or WITS, http://wits.worldbank.org);

- lndist: is the log of distance measured in kilometres between trading partners' capital cities used as proxy for transaction costs;

- border: dummy, takes value 1 if the two countries share a common border

- Euro: dummy, takes value 1 if both countries are members of Eurozone and zero otherwise. 
- $\quad O M S$ : dummy, takes value 1 if both countries are old member states and zero otherwise;

- $\quad$ NMS: dummy, takes value 1 if both countries are new member states and zero otherwise;

- NMSOMS: dummy, takes value 1 if the reporter country is new member state and the partner country is old member states and zero otherwise.

\section{Results and discussion}

The large number of unit root tests with varying deterministic specifications are not included in this paper, yet available upon request. In our single equation estimation and testing framework, each country in a price pair is considered both as a dependent and as an independent variable. Thus, using the logarithm of the 20 member state prices depicted in Figure 2, a total of 380 price pairs ( $k(k-1)$, where $k=20$, the member of countries considered in this paper) were tested for cointegration and $135(35 \%)$ proved to be cointegrated. Pairwise cointegration tests were run in the Engle and Granger framework (Engle and Granger, 1987). The weak LOP restriction $\left(\beta_{1}=1\right)$ could not be rejected in 63 cases, that is $16.5 \%$ of all possible price pairs and $46 \%$ of cointegrating price pairs. Next, a LOP binary variable is created that contains 63 entries of unity for country pairs where the restriction holds, and 72 entries of zeros totalling 135 observations. To ensure consistency, we estimated four models (M1-M4): with and without border dummy and with both log trade value and quantity. The upper part of Table 1 presents the estimation output of the semi-nonparametric discrete-choice model (SNP) of Gallant and Nychka (1987), the lower part displays the number of observations, log likelihood, Wald test of all zero coefficients, Akaike information criteria and most importantly, the p-value of the chi2 test of Probit model against SNP model. (SNP procedure is implemented in STATA package, see De Luca (2008).) Note, the number of observations decreased from 135 to 108 , since not all cointegrating price pairs are actually involved in physical trade.

Our primary interest here are not the magnitude, but rather the sign of coefficients. Very robust results were obtained: trade value and quantity parameters are significant beyond .001 , as is the trade cost (log distance) coefficient. In line with our a priori expectations, trade cost negatively affects market integration, whilst increasing trade activity boosts integration. Country group dummies except NMS are significant at $5 \%$, and have consistent signs, suggesting that price transmission is more complete if both the exporter and importer countries are Old Member States (positive coefficient of OMS). The positive coefficient of NMSOMS dummy (i.e. the reporting exporter country is a NMS trading with an OMS) suggests stronger integration, perhaps possible to interpret as NMS are following OMS price signals. This seems plausible, since besides orienting towards the core of EU countries, (except Poland, 6th largest producer) New Member States are generally smaller both in terms of population and milk production. The positive coefficient on the Euro dummy emphasizes that membership in the Eurozone results in more profound milk market integration.

\begin{tabular}{|c|c|c|c|c|}
\hline & M1 & M2 & M3 & M4 \\
\hline Lnexport & $.184 * * *$ & $.179 *$ & & \\
\hline Lnexportq & & & $.156^{* * *}$ & $.150 * * *$ \\
\hline Lndist & $-.716 * * *$ & $-.363 * * *$ & $-.786 * * *$ & $-.536 * * *$ \\
\hline Border & -1.373 & & -1.284 & \\
\hline Euro & $1.232 *$ & $.985 * *$ & $1.101 *$ & $.932 * *$ \\
\hline OMS & $.940 *$ & $.663 *$ & $.906 *$ & $.746^{*}$ \\
\hline NMS & .086 & -.708 & -.086 & -.960 \\
\hline NMSOMS & $1.599 *$ & 1.688 & $1.307 *$ & $1.249 *$ \\
\hline cons (fixed) & 3.164 & .782 & 2.752 & .463 \\
\hline $\mathrm{N}$ & 108 & 108 & 108 & 108 \\
\hline 11 & -58.85 & -60.22 & -58.9 & -60.08 \\
\hline Wald chi ${ }^{2}$ & 674.8 & 73.36 & 529.95 & 119.37 \\
\hline $\mathrm{AIC}$ & 139.71 & 140.45 & 139.81 & 138.16 \\
\hline P (Probit against snp) & 0.029 & 0.018 & 0.02 & 0.003 \\
\hline
\end{tabular}


Albeit focusing on the correction coefficient (speed of adjustment) and not on LOP, our results show strong similarities with the findings of Holst and von Cramon-Taubadel (2013) on the European pork market, i.e. faster transmission (stronger integration) between OMS, Eurozone members if trade-costs are low (proxied by common border in the referred paper).

By estimating the LOP restriction to all possible country pairs in the first stage, we implicitly assumed that price information might flow even without physical trade. Traditionally (horizontal) price transmission and market integration is considered trade driven. There is however evidence that error correction between price margins, and thus market equilibrium happens both with and without trade if distinct markets monitor each other's prices. Stephens et al. (2012) use tomato prices with actual trade-flow and trade-cost data to estimate a Hansen (2003) type fully flexible error correction model allowing for separate trade and non-trade regimes. Although the authors expected that during no-trade periods prices are not adjusting towards the long-run equilibrium, empirical analysis proved cointegrated prices and adjustment in both regimes, implying multiple spatial equilibria (with and without actual trade flows). Similar conclusion, i.e. 'physical trade is not a necessary condition for price transmission' was reached by Holst and von Cramon-Taubadel (2013, p. 20.) with respect to horizontal integration of European pork markets. Although from a completely different perspective and methodology, it supports our finding of cointegration, i.e. equilibria for some country pairs not actually engaged in physical trade. More, in this paper we also found a fair number of country pairs where the LOP holds, yet are not engaged in trade.

To sum up, our paper uses a completely different methodology to reach the conclusion of Kouyaté and Cramon-Taubadel (2016 pp. 269): 'for those who criticize PT analysis as lacking an adequate theoretical basis, these results might provide some reassurance that empirical PT studies are on the whole producing consistent and plausible results.' A key issue of our paper is the relatively low number of occurrence of pairwise cointegration on the milk market. Whilst Holst and von Cramon-Taubadel (2013) rejected the null of no cointegration in 103 cases of the possible $105(98 \%)$ ). (We are aware that the referred paper employs a different approach, i.e. system cointegration with one cointegrationg vector versus our single equation approach considering each partner both as dependent and independent variable, yet the difference between frequency of no-cointegration rejection on pork and milk markets is striking.) Our analysis resulted in a much lower rejection rate $(35 \%)$. Does this finding point to lower degree of market integration of milk (defined here at its least restrictive form, co-movement of prices), compared to pork markets? It might as well just be so, when one considers the rather different way raw milk and pork markets are organised in space. Whilst transport of live pigs to slaughterhouses and processor plants from a given region occurs at given (larger) intervals and at lower unit costs, raw milk collection by processors is an (almost) daily business (depending on local cooling facilities) limiting spatially the radius processors can reach. Thus it is likely that prices are formed around milk collecting hubs, not necessarily within national borders. Consequently, national prices (at least within the EU) might not be fully representative for all of the given country's geographic regions. The availability of EU-wide regional prices would almost certainly change results.

\section{Conclusions}

We assess the horizontal integration of raw milk markets in 20 EU member states accounting for roughly $98 \%$ of milk production in the EU for a period covering the past 13 years. Results suggest the cointegration of milk prices is less prominent than that of other agricultural sectors. More, the pairwise LOP only holds in $16.5 \%$ of all possible cases, raising questions with respect to the efficiency of markets, and perhaps applicability of national price data. Second stage analysis emphasised the positive role trade volume plays in strengthening market integration, although results (in line with other recent papers) highlighted that physical trade in not a necessary precondition of integration and market equilibria. It appears that OMS and Eurozone member states are better integrated compared to NMS, yet there is some evidence for interregional relationships (OMS, NMS) accelerating integration. 
Corresponding authors

Zsófia Benedek, PhD.

Institute of Economics, Centre for Economic and Regional Studies of the Hungarian Academy of Sciences

Tóth Kálmán u. 4., 1097 Budapest, Hungary

Phone: +36 305071 019, Email: benedek.zsofia@krtk.mta.hu

\section{References}

[1] Bakucs, Z., Fałkowski, J. and Fertő, I. (2014) "Does Market Structure Influence Price Transmission in the Agro-food Sector? A Meta-analysis Perspective“, Journal of Agricultural Economics, Vol. 65, No. 1, pp. 1-25. ISSN 1477-9552. DOI 10.1111/1477-9552.12042.

[2] Bakucs, Z., Bojnec, Š. and Fertő, I. (2015) "Spatial Product Market Integration between Two Small, Open Neighbouring Economies“, Agribusiness, Vol. 31, No. 2, pp. 171-187. ISSN 1520-6297. DOI 10.1002/agr.21399.

[3] Barrett, C. B. (2001) "Measuring integration and efficiency in international agricultural markets“, Review of Agricultural Economics, Vol. 23, No. 1, pp. 19-32. ISSN 1467-9353. DOI 10.1111/1058-7195.00043.

[4] Bojnec, Š. and Fertő, I. (2014) "Export competitiveness of dairy products on global markets: The case of the European Union countries“, Journal of Dairy Science, Vol. 97, No. 10, pp. 6151-6163. ISSN 0022-0302. DOI 10.3168/jds.2013-7711.

[5] Bouamra-Mechemache, Z., Jongeneel, R. and Réquillart, V. (2008) "Impact of a gradual increase in milk quotas on the EU dairy sector", European Review of Agricultural Economics, Vol. 35, No. 4, pp. 461 - 491. ISSN 1464-3618. DOI 10.1093/erae/jbn044.

[6] Brosig, S., Glauben, T., Götz, L., Weitzel, E.B. and Bayaner, A. (2011) "The Turkish wheat market: spatial price transmission and the impact of transaction costs", Agribusiness, Vol. 27, No. 2, pp. 147-161. ISSN 1520-6297. DOI 10.1002/agr.20257.

[7] De Luca, G. (2008) "SNP and SML estimation of univariate and bivariate binary-choice models", Stata Journal, Vol. 8, No. 2, pp. 190-220. ISSN 1536-8734. DOI 10.1177/1536867X0800800203.

[8] EDA (2014) "Economic Report 2014“, Brussels, Belgium: European Dairy Association. [Online]. Available: http://eda.euromilk.org/fileadmin/user_upload/Public_Documents/Facts_and_Figures/ EDA_Economic_Report_2014_.pdf [Accessed: 10 Jan. 2019].

[9] Emmanouilides, C. J. and Fousekis, P. (2015) "Assessing the Validity of the LOP in the EU Broiler Markets“, Agribusiness, Vol. 31, No. 1, pp. 33-46. ISSN 1520-6297. DOI 10.1002/agr.21386.

[10] Enders, W. (2010) "Applied econometric time series“ (New York: John Wiley \& Sons, 2010). ISBN 978-0470505397.

[11] Enders, W. and Siklos, P. L. (2001) "Cointegration and threshold adjustment", Journal of Business \& Economic Statistics, Vol. 19, No. 2, pp. 166 - 176. ISSN 1537-2707. DOI 10.1198/073500101316970395.

[12] Engle, R. F. and Granger, C. W. J. (1987) "Co-integration and error correction: representation, estimation, and testing", Econometrica: Journal of the Econometric Society, Vol. 55, No. 2, pp. 251-276. ISSN 1468-0262. DOI 10.2307/1913236.

[13] Esposti, R. and Listorti, G. (2013) "Agricultural price transmission across space and commodities during price bubbles“, Agricultural Economics, Vol. 44, No. 1, pp. 125-139. ISSN 1477-9552. DOI 10.1111/j.1574-0862.2012.00636.x.

[14] Gallant, A. R. and Nychka, D. W. (1987) "Semi-nonparametric maximum likelihood estimation", Econometrica: Journal of the Econometric Society, Vol. 55, No. 2, pp. 363-390. ISSN 1468-0262. DOI $10.2307 / 1913241$. 
[15] Goetz, L. and von Cramon-Taubadel, S. (2008) "Considering threshold effects in the long-run equilibrium in a vector error correction model: An application to the German apple market", $12^{\text {th }}$ Congress of the European Association of Agricultural Economists, pp. 1-12. [Online]. Available: https://ageconsearch.umn.edu/bitstream/44247/2/511.pdf [Accessed: 10 Jan. 2019].

[16] Gonzalo, J. and Pitarakis, J.Y. (2006) "Threshold Effects in Cointegrating Relationships", Oxford Bulletin of Economics and Statistics, Vol. 68, pp. 813-833. ISSN 1468-0084. DOI 10.1111/j.1468-0084.2006.00458.x.

[17] Greb, F., Jamora, N. Mengel, C. von Cramon-Taubadel, S. and Würriehausen, N. (2012) "Price transmission from international to domestic markets", GlobalFood Discussion Papers, 2012. [Online]. Available: https://openknowledge.worldbank.org/bitstream/handle/10986/24054/ Price0transmis00to0domestic0markets.pdf? sequence $=1$ \&isAllowed=y [Accessed: 10 Jan. 2019].

[18] Hansen, B. E. and Seo, B. (2002) "Testing for two-regime threshold cointegration in vector errorcorrection models“, Journal of Econometrics, Vol. 110, No. 2, pp. 293-318. ISSN 0304-4076. DOI 10.1016/S0304-4076(02)00097-0.

[19] Hansen, P. R. (2003) "Structural changes in the cointegrated vector autoregressive model", Journal of Econometrics, Vol. 114, No. 2, pp. 261-295. ISSN 0304-4076. DOI 10.1016/S0304-4076(03)00085-X.

[20] Holst, C. and von Cramon-Taubadel, S. (2013) "Trade, market integration and spatial price transmission on EU pork markets following Eastern enlargement", Diskussionspapiere, Department für Agrarökonomie und Rurale Entwicklung, 2013. [Online]. Available: https://www.econstor.eu/ bitstream/10419/85348/1/770138012.pdf [Accessed: 10 Jan. 2019].

[21] Kouyaté, C. and von Cramon-Taubadel, S. (2016) "Distance and Border Effects on Price Transmission: A Meta-analysis“, Journal of Agricultural Economics, Vol. 67, No. 2, pp. 255-271. ISSN 1477-9552. DOI 10.1111/1477-9552.12145.

[22] Listorti, G. and Esposti, R. (2012) "Horizontal price transmission in agricultural markets: fundamental concepts and open empirical issues", Bio-based and Applied Economics, Vol. 1, pp. 81-108. ISSN 2280-6172. DOI 10.13128/BAE-10769.

[23] Phillips, P. C. and Hansen, B. E. (1990) "Statistical inference in instrumental variables regression with I (1) processes“, The Review of Economic Studies, Vol. 57, No. 1, p. 99-125. ISSN 1467-937X. DOI 10.2307/2297545.

[24] Stephens, E. C., Mabaya, E., von Cramon-Taubadel, S. and Barrett, C. B. (2012) "Spatial price adjustment with and without trade“, Oxford Bulletin of Economics and Statistics, Vol. 74, No. 3, pp. 453-469. ISSN 1468-0084. DOI 10.1111/j.1468-0084.2011.00651.x.

[25] Tomek, W. G. and Robinson, K. L. (2003) "Agricultural Product Prices“, Ithaca and London: Cornell University Press, 2003. ISBN-10 9780801440939, ISBN-13 978-0801440939.

[26] Westhoek, H., Rood, G., Van den Berg, M., Janse, J., Nijdam, D., Reudink, M., Stehfest, E., Lesschen, J. P., Oenema, O. and Woltjer, G. (2011) "The Protein Puzzle: The consumption and production of meat, dairy and fish in the European Union", The Hague: Netherlands Environmental Assessment Agency. ISBN 9789078645610 - 218. 